Máire ní Fhlathúin, University of Nottingham

Late Orientalist poetry and politics: India in the colonial literary culture of the $1830 \mathrm{~s}$

\begin{abstract}
As British rule in India took an increasingly Anglicist and Utilitarian-influenced turn in the 1830s, there nevertheless persisted some remnants of the Orientalist approach to Indian culture associated with the scholarship of William Jones. This essay explores the work of William Francis Thompson (1810-1842), whose poetry and literary translations develop an unusually sympathetic identification with both colonizer and colonized subjects. It argues that Thompson's recognition of parallels between European and Indian nationalism enables an alternative perception of British rule; and that his work highlights the eclectic and complex character of the colonial literary culture of British India.
\end{abstract}

William Francis Thompson travelled to Bengal as a civil servant of the East India Company in 1829, lived and worked there for most of the following thirteen years, during which he also wrote several works of translation and poetry, and died as a result of suicide in 1842. A brief contemporary death notice records that he had been 'for some time labouring under an aberration of mind'.1 Though suicide brought his life to an untimely end, the other details of Thompson's career and existence in India are unremarkable, reflecting those of many other Company employees of this period: the pages of the Bengal Annual, in which several of his shorter poems first appeared, are filled largely with writings produced by those who were full-time civil servants or military officers, but amateur and part-time writers.2 This essay starts from this point of paradox, considering that the combination of obscure and overfamiliar is a characteristic Thompson shares with many other colonial writers who lived and died in British India, whose work makes up the increasingly well-known, though still underinvestigated, tradition of this literature. It combines new biographical research and a wideangle survey of Thompson's writing in the context of Romantic-period literature and political discourse in Europe and India, with the aim of highlighting his position at the intersection of a series of intellectual and literary cross-currents. In doing so, it argues that the sometimes

1 Asiatic Journal, February 1843, p. 149.

2 The exceptions are David Lester Richardson, described as 'the only man in India who has made literature a profession' (Calcutta Courier, 28 Dec 1835) and Emma Roberts, who combined poetry with the more lucrative pursuit of journalism. Both had a higher profile than Thompson, and a wider readership.

Ní Fhlathúin 1 
apparently one-dimensional literature of British India is both complex and multi-determined, even at its provincial margins; and that Romantic-period concerns with political and poetic individualism take unexpected forms at their intersection with the lived experience of colonialism from the point of view of the colonizer.

\section{Thompson's life and work}

Most of Thompson's work deals with India, in one form or another. India: A Poem (1834), a work targeting the policies and administration of the East India Company, was published under the pseudonym of 'a young civilian of Bengal'. Around the same time, a series of shorter poems appeared in the Bengal Annual: these were less controversial in subject-matter than India, but many deal with similar themes - in essence, the imaginative engagement with aspects of India and its people; and the representation of the author's experience as a British man in India. Revised versions of some of these poems appear in The City of the East (1837), alongside the eponymous long poem which opens the collection, an intense and at times nightmarish vision of the British encounter with India. Thompson left India on medical leave in 1835, travelling to Australia and thence to Britain, where he stayed until May 1839; during this time he published several translations and scholarly discussions of Oriental works, as well as a selection of the letters and poems of his late brother, George Frewin Thompson (1804-1834), also a Company employee. A marriage to Jane Wilson took place in 1838, followed by the birth of a son, William Frewin, in April 1839. The family returned to India shortly afterwards, and Thompson resumed his civil service employment in the NorthWestern Provinces. Jane gave birth to a daughter, Frances Jane, in 1840. Towards the end of 1842, Thompson left his post at Gorakhpur and travelled to Agra, where he committed suicide on 20 December 1842. His possessions were sold at auction, the normal procedure following a European death. Jane applied to the Bengal Civil Fund for a pension for herself and her children, and she and they eventually returned to Britain. 3

Thompson's work attracted little critical interest during his life or after his death. India: A Poem received some attention at the time of its publication, and was re-printed during the postcolonial period.4 Another poem, 'Indian Revelry' (1835), had a wide

\footnotetext{
3 This account draws on and supplements the introduction to Thompson's work in The Poetry of British India, ed. by Máire ní Fhlathúin, 2 vols (London: Pickering \& Chatto, 2011), II, 1-2; other sources include contemporary notices in the Asiatic Journal, the Friend of India and other newspapers; and India Office records of baptisms and burials (N/1) held in the British Library, London.

4 India: A Nineteenth Century Study of British Imperialism in Verse, ed. by B. M. Sankhdher (New Delhi:

Kumar, 1972).
}

Ní Fhlathúin 2 
circulation into the twentieth century, but soon became detached from its author's name.5 The particulars of his life listed above are obtained from East India Company records and notices in periodicals; no personal documents or more extensive papers have so far come to light. In the absence of detailed or reflective auto/biographical material, and in particular of any account of the mental disorder that apparently led to his suicide, Thompson's life and death never come into sharp focus, even while the broad outlines of his career conform to the familiar shape of the East India Company civil servant.

This essay represents an attempt to refocus critical attention on a writer who is at once representative and unconventional. It explores the ways in which Thompson's work and thinking were shaped by his interest in Eastern, and particularly Islamic, languages and texts, locating him in the tradition of thought most associated with William Jones and late eighteenth-century attitudes to the Orient, and therefore setting him also at odds with the Anglicist mindset of those — such as James Mill and Thomas Macaulay_who succeeded Jones, and in whose work the business of colonial administration was less inflected by eighteenth-century ideas of trans-cultural sympathy. There follows an analysis of Thompson's self-fashioning as a poet, tracing his engagement with networks of thought and discourse extending well beyond British India; in particular, he co-opts the discourse of 1820s and 1830s European nationalism, as well as adapting some metropolitan traditions of English poetry. The essay goes on to investigate his work as it constitutes a record of, and response to, the writer's quotidian life in India, considering Thompson as one of the 'Company poets' of the 1820 s and 1830 s, when disillusion with India, and with the elite classes of the British administration, among lower-level employees contributed to a body of aggressively satirical representations of the British encounter with India. Finally, I consider the part to be played by such analyses as these in shaping the larger critical project of retrieval, returning to a basic question: what is to be gained by the study of such minor or marginal works and writers?

\section{Thompson, Jones and the legacy and persistence of Orientalist thought}

The process of translation is key to the production of colonial knowledge, its essence being the means by which two languages, and thereby two cultures, encounter one another. Thompson's work as translator (comprising both literal translation and the imaginative

5 William Francis Thompson, The City of the East and Other Poems (London: Priestley, 1837), pp. 57-60; see also C. H. Ward-Jackson, 'The Singular Case of "The Revel”, Blackwood's Magazine, 316 (Oct 1974), 324338. 
inhabitation of another culture) is strongly influenced by Jones's scholarship, but also by Jones's approach to Eastern cultures. Jones-legal scholar, Orientalist, and founder of the Asiatick Society of Bengal—dominated British approaches to Indian cultures and languages in the last decades of the eighteenth century. Alongside the body of work resulting from his years of translation and dissemination of Eastern texts, his achievements as linguist and translator transformed Britain's knowledge of the East, and brought about, in the influential 'Third Anniversary Discourse' (positing the one-time existence of a proto-Indo-European language), the 'world-modifying' shift in perception that saw some aspects of Eastern cultures and languages set on a level with, and of comparable status to, those of Europe. 6 Thompson was familiar with a range of Jones's works; he possessed several volumes of the Transactions of the Asiatic Society as well as A Grammar of the Persian Language, and his own practice of translation was carried out in active dialogue with that of his predecessor.7 The analysis that follows sets Thompson's work in the context of Jones's discussion of Eastern and Western cultures in the 'Second Anniversary Discourse' to the Royal Asiatic Society (1785), and, briefly, in the context of his translations and adaptations of Eastern poetry.

By the time Thompson arrived in India in 1829, thirty-five years after Jones's death, both the society of British India and the prevailing approach to the languages and cultures of the East had been transformed. The production of 'colonial knowledge'-including Oriental scholarship, but also other forms of information about the geographical, political and social makeup of the Indian subcontinent — had become the preserve of Europeans, and was driven by 'European needs and preconceptions'.8 While Jones had worked alongside Indian colleagues such as Jagannātha Tarkapañcānana, his collaborator on the work eventually published in translation after his death as A Digest of Hindu Laws, such figures had disappeared from the landscape of the early nineteenth century.9 Jones's early sense of the East as intrinsically inferior to Europe - 'mere children' to Europe's adulthood in the fields

6 William Jones, 'Third Anniversary Discourse', Asiatic Researches, 1 (1799), 415-431; see Michael J. Franklin, Orientalist Jones: Sir William Jones, Poet, Lawyer, and Linguist, 1746-1794 (Oxford: Oxford UP, 2011), p. 36. 7 William Francis Thompson, 'Remarks on Ameer Khosroe's Lylee and Mujnoon', Bengal Annual 6 (1835), 387-405 (p. 389). For a list of books and other items in Thompson's possession at his death, see Inventories and Accounts of Deceased Estates - Bengal, Madras and Bombay 1843, part 2, fols. 16-31 (London, British Library, IOR L/AG/34/27/127).

8 P. J. Marshall, 'British-Indian Connections c. 1780 to c. 1830: The Empire of the Officials', in Romantic

Representations of British India, ed. by Michael J. Franklin (London \& New York: Routledge, 2006), pp. 45-64 (p. 54).

9 H. T. Colebrooke, A Digest of Hindu Law on Contracts and Successions (Calcutta, 1798).

Ní Fhlathúin 4 
of 'the sciences' - is echoed in the nineteenth century, but unleavened by the increasing respect he later developed for Eastern learning. 10 His metaphor of childhood anticipates Thomas Macaulay, whose infamous 'Minute on Indian Education' sets Eastern learning at a level that would 'move laughter in girls at an English boarding school'.11 The Anglicist approach to India went further in this respect, however: James Mill's influential History of British India (1818) downgrades Hindu culture and civilization, and does so by taking issue with Jones's evaluation of the Sanskrit language and the Hindu religious and social order.12 By the 1820s and 1830s British India no longer took its cue, in so far as it ever had done, from Jones's approach to the East.

Thompson was educated to take part in the East India Company's administration, trained at Haileybury, where he was awarded prizes in several subjects, and ranked first among the cohort of students bound for Bengal.13 He was also a keen linguist and translator, and it is his work in this field that suggests how his thinking is at odds with the post-Jonesian mindset prevailing in British India. In discussing his Practical Philosophy of the Muhammadan People ... from the Persian of Fakīr Jāny Muhammad Asäad (1839), he sets his task of translation in the context of instrumental learning, and aligns it, and himself, with the colonial agenda of the East India Company. 'The translation of this abstruse and elaborate work', he writes, 'was undertaken principally in order to illustrate and exemplify the resources of Persian literature, with a view to their bearing upon a question of great practical

10 William Jones, 'Second Anniversary Discourse', Asiatic Researches, 1 (1799), 405-414 (p. 411 ). See Franklin, Orientalist Jones, pp. 222-3. On Jones's evaluation of the East relative to Europe, see also Thomas R. Trautmann. Aryans and British India (Berkeley: University of California Press, 1997), p. 60; and on the extent and limits of Jones's 'sympathetic vision' of the East, see Andrew Rudd, Sympathy and India in British Literature, 1770-1830 (Basingstoke: Palgrave Macmillan, 2011), pp. 56-86). The extensive scholarly debate on Jones and the question of Orientalism / orientalism is beyond the scope of this essay, but a useful summary is offered by Tara Ghoshal Wallace, Imperial Characters: Home and Periphery in Eighteenth-Century Literature (Lewisburg: Bucknell UP, 2010), pp. 212-13, note 53). The important point here is not so much Jones's role as part of the colonialist machine — a role he undoubtedly played — but the difference of kind and degree between his approach to the East and to India, and the attitude of those later officials of the East India Company who succeeded him. In this essay, I have used 'Orientalism' (capitalized) to refer to the scholarship and approach of Jones, and orientalism (lower-case) to indicate a reference to the set of Western attitudes, discourses and institutions regarding the East suggested in Edward Said, Orientalism, 2nd edn. (London: Penguin, 2003). There is, clearly, a wide area of overlap between them.

11 Thomas Babington Macaulay, 'Minute on Indian Education' (1835), in Revolutions in Romantic Literature: An Anthology of Print Culture, 1780-1832, ed. by Paul Keen (Peterborough, Ontario: Broadview Press, 2004), pp. 313-315 (p. 314).

12 Theodore Koditschek, Liberalism, Imperialism, and the Historical Imagination: Nineteenth-Century Visions of a Greater Britain (Cambridge: Cambridge UP, 2013), pp. 82-83).

13 Asiatic Journal, July 1828, pp. 64-65.

Ní Fhlathúin 
importance in our Eastern possessions'.14 But he also goes out of his way to respond to, and reject, the denigration of Eastern civilizations engaged in by writers such as Mill and Macaulay:

Of late years it has become a favourite position with those who know not how to explain by any more modest or humane theory the social degradation of the Asiatic people, to attribute it to some radical error in their scientific systems; in other words, to a want of average capacity in the inhabitants of that half of the globe to which the supposers do not happen to belong. The consequences they deduce are worthy of the liberality of their premises; - that Asiatic learning must be extirpated root and branch and replaced by that of Europe. (xxiv)

Repudiating this way of thinking, Thompson instead returns to the worldview suggested by Jones in the 'Second Anniversary Discourse', where Eastern and Western traditions are considered side by side, suggesting equivalences, congruences, and unities (though not intellectual parity) between the two.15 'Muhammedan philosophy', Thompson argues, 'is neither more nor less than Grecian philosophy in an Eastern garb, a twin offspring of that common parent from which the sciences of Europe are proud to acknowledge their derivation' (xxv). His edition points out sources for the Islamic text in Aristotle, but also uses an extensive textual apparatus to outline a set of cognates between the two traditions. These notes reference the Koran, Shakespeare, the Bible, the Arabian Nights, Augustine's City of God, Boswell on Samuel Johnson, and Machiavelli, among other sources; they often take the form of responses to or indications of cross-textual elements of commonality, rather than simple glosses. While there is clearly an element of self-indulgent demonstration of wide reading here, the invocation of multiple texts has the substantive effect of constructing the Practical Philosophy as indicative of a current of human thought shared across traditions.

Conversely, Thompson's work also follows that of Jones in assuming the inferior status of the East, in Jones's formulation, an Asiatic 'handmaid' to Europe's 'sovereign Princess'. 16 The observation that 'in modern Europe ... more has been done to solve the great problem of human felicity than at any previous epoch of the world' (xx) is made without apparent reservation. Its unquestioned Eurocentrism informs Thompson's account of translation as the task of his 'leisure' time; and informs also his description of the Practical

14 W. F. Thompson, Practical Philosophy of the Muhammadan People ... from the Persian of Fakīr Jāny Muhammad Asäad (London, 1839), p. xxiv. Further references are included in the text.

15 Jones, 'Second Anniversary', pp. 407-412.

16 Jones, 'Second Anniversary', p. 406. 
Philosophy as 'a curious and in the East a celebrated work' (vi) — what is celebrated in the East is a curiosity in the West.

A similar combination of scholarly interest and condescension is apparent in Thompson's 'Review of the Makámát ul Harírí' (1839), a collection of fifty short prose/poetry narratives, or maqāmāt, compiled by Ibn al'Harīīi in early twelfth-century Baghdad. Thompson's discussion of this work considers translation as an undertaking of cultural immersion:

A language must be known in its familiar and habitual applications; its relations to all the characteristics of a people and a country, must not only be understood, but felt, pursued, and admired by foreigners, before the merits of style can be properly appreciated. We must wander with them over their deserts, watch with them beneath their skies - join in the pride of the past - the capriciousness of the present - the carelessness of the future - master every national peculiarity, and delight in eachbefore we can enter into the intellectual system that resulted from the whole.17 Again, this account is contradictory in its imagination of the cross-cultural self/other divide: while the task of comprehension and empathy is accepted to be that of the 'foreigners', among whom the translator counts himself, the text also recreates the relationship of superiority between those foreigners and those whose characteristics are to be 'master[ed]'. Those same characteristics are described using a casually derogatory cline of degeneration, where 'capriciousness' and 'carelessness' are the successor qualities to the 'pride of the past'. A similar sense of the essential difference, and inequality of status, between east and west is apparent in Thompson's discussion of his own approach to translation in 'Remarks on Ameer Khosroe's Lylee and Mujnoon' (1835). 'There is no symmetrical construction of period' in this text, he writes, 'no harmonious correspondence of parts, no gradual evolution' ${ }_{18}$ Confronted with these deviations from a European norm, he chooses to adopt a 'middle course': 'Where the offence is venial, the original allusion has been preserved entire; where it is such as unpractised readers could not tolerate, it has been softened down to that degree of strangeness which seems but necessary to keep up the impression of its being a Persian love-tale' (389).19 The language of 'offence' is used in this passage to stigmatize

17 W. F. Thompson, 'A Review of the Makámát ul Harírí', Journal of the Royal Asiatic Society, 5 (1839), 201215 (p. 201) 18 Thompson, 'Remarks', p. 388.

19 Here I read against the grain of Thompson's own discussion of the difference between his own practice and that of Jones, of whom he acidly remarks that 'his prose is not to be read, and his poetry is not to be trusted' ('Remarks', p. 389). Nonetheless, Thompson's formulation of the translator's role in terms of mitigating the 
Eastern difference from an explicitly Western norm with which the translator identifies himself, and its explicit concern is to lessen that difference to a degree which makes it inoffensive or unthreatening - tolerable for the practised reader at least - while retaining the 'impression' of otherness. This might be considered a project of cultural mediation, rather along the same lines as the Practical Philosophy discussed above; but it is also telling in its combination of imaginative sympathy and intellectual condescension, both echoing the note struck by Jones in his 'Second Anniversary Discourse' formulations of the relationship between East and West.

Thompson's poetry also signals his interest in, and imitation of, Jones's practice of producing poetic forms of representation of the 'other', where an imagined Indian voice is inflected by contemporary British concerns and values. Several of Jones's best-known works are written in the voice of a Hindu poet. The 'Hymn to Ganga', for instance, is 'feigned to have been the work of a Bráhmen, in an early age of Hindu antiquity'.20 This work shows both the extent and the limits of Jones's ability to adopt the point of view of the colonized, as the speaker 'by a prophetical spirit, discerns the toleration and equity of the British government, and concludes with a prayer for its peaceful duration under good laws well administered' (124). While Jones thus had his Brahmin subject prospectively celebrate British achievements, the vision he creates is one of an enlightenment colonialism, where the 'peerless race' of the colonizers are possessed of both 'lib'ral heart and martial grace', and thus able to conserve that which is good in Hindu society even while they impose security: 'As they preserve our laws, and bid our terror cease, | So be their darling laws preserv'd in wealth, in joy, in peace!' (132).

Thompson, similarly, evolved imaginary vocal others, thus carrying on both a Romantic tradition of ventriloquism in poetry and an imperial tradition (going back to Thomas Gray's 'The Bard' and Macpherson's Ossian poems) of using the voice of the colonized to memorialize vanquished cultures.21 Unlike Jones, his Indian subjects do not perform the convenient acquiescence of the colonized. His poem 'The Jogi's Address to the

alienating aspects of the source text is not materially different from that Jones assumes in his famous translation 'A Persian Song of Hafiz', with its deft elision of the mole on the face of its feminized subject (see Sir William Jones: Selected Poetical and Prose Works, ed. by Michael J. Franklin (Cardiff: University of Wales Press, 1995), p. 186. This poem and its translations are featured in Jones's widely-used work A Grammar of the Persian Language (London, 1771), pp. 101, 137-40, and would certainly have been known to Thompson. 20 Franklin, Jones: Selected Works, p. 124. Further references are included in the text.

21 See Tim Fulford, 'Poetry, peripheries and empire', in Cambridge Companion to British Romantic Poetry, ed. by James Chandler and Maureen N. McLane (Cambridge: Cambridge UP, 2008), pp. 178-194 (pp. 179-180). 
Ganges' reprises Jones's 'Hymn to Ganga' while rejecting entirely the idea of 'peace' as a colonizer-fostered good:

Say is it that thou loath'st the land

Where pallid mullicks22 reign?

Then aid, oh aid our feeble hands,

Or we shall fight in vain:

For think not that we tamely bow,

To be the things we are,

No, they are strong, but—Ganges thou,

Oh thou art stronger far.

The poem ends with the speaker's lament for the loss of 'our sway, our land, our name' in the 'grief and shame' of subjection, and the unanswered cry to the Ganges 'where art thou-oh where?'23 Elsewhere, Thompson imagines the Ganges post-uprising, as the incarnation of India resurgent:

Vast Ganges rises in his ruddy bed,

And plays exulting with the rocking dead,

Taunting the chastened Ocean as he runs

With the swollen relics of its mighty sons.24

Such works point to an identification with the subjugated other that goes well beyond Jones's imagination of a Brahmin cheerleader for British rule, and takes Thompson out of the category of those, like Jones, who use 'an indigenous idiom' as 'a vehicle for legitimising British rule'.25 Mulholland develops a more nuanced interpretation of the polyphonic texts written by Jones and his contemporaries, suggesting that rather than simply constituting an example of 'appropriation', the illusion of the speaking other could also establish 'an unstable yet reciprocal intimacy among readers and fantasized colonial voices', thus enabling the text 'to register types of anticolonial thought that are complexly intermixed with imperial

22 An earlier version of the poem has this phrase as 'pale-faced Mlechhas', that is, foreigners or those outwith the Hindu caste system (Bengal Annual, 1834, p. 233).

23 Thompson, City of the East, p. 41.

24 W.F. Thompson, India: A Poem, in Three Cantos, by a Young Civilian of Bengal (London: Priestley, 1834), p. 87. Further references to this work are included in the text.

25 Nigel Leask, 'Towards an Anglo-Indian poetry? The colonial muse in the writings of John Leyden, Thomas Medwin and Charles D'Oyly', in Writing India 1757-1990, ed. by Bart Moore-Gilbert, pp. $52-85$ (p. 57); see also Javed Majeed, Ungoverned Imaginings: James Mill's The History of British India and Orientalism (Oxford: Clarendon Press, 1992), p. 24. 
power'.26 In Thompson's work, the balance is heavily weighted towards this 'anticolonial thought', transforming Jones's domesticated Brahmin and vision of colonial stability into a series of figures of active and successful insurrection. With this transformation, Thompson's work is clearly marked as constituting both a legacy of Orientalist thought and an attempt to repudiate orientalist (in the Saidean sense) attitudes, incorporating an identification with both the colonizer and the colonized. The following sections of this essay explore this aspect of his work further, considering first the impact of colonialism in India, and secondly the impact of participation in colonialism for British men in India, including Thompson himself.

\section{From Orientalism to nationalism: India}

Several aspects of Thompson's work reflect the growth of interest in European nationalist movements during the 1820 s and 1830 s, and in particular the trope of national liberty pursued in the face of oppression and tyranny. This trope proliferates in the print culture of both metropolis and colony, at a time when the newspapers were discussing the opportunities for 'young Englishmen of distinction' to bear arms in the movement for Greek liberation from 'infidel despotism'.27 In the sphere of poetry, Byron's foundational Don Juan, with its evocative, though satiric, meditation on the 'Isles of Greece', appeared in the British press in India. So also did works by Thomas Campbell, including stirring descriptions of individual fervour for liberty such as the 'Song of the Greeks', with its exhortation to 'bid the tyrants defiance' and the 'Spanish Patriot's Song' in which the speaker holds that 'There is a victory in dying well | For Freedom'.28 In India, the discourse of nationalism and the quest for liberty found an echo in the work of James Tod, whose Annals and Antiquities of Rajast'han (182932) developed a narrative of the Rajput states as engaged in a heroic, if ultimately futile, struggle against Muslim invasion, though this struggle takes place long before the expansion of the British colonial state across India from the mid-eighteenth century onwards. 29 Thompson's 'Rajpoot's Lament' similarly sets up a Rajput identity of heroic failure - the protagonist imagining his own death compensated for by a future reversal of fortune, when

26 James Mulholland, Sounding Imperial: Poetic Voice and the Politics of Empire, 1730-1820 (Baltimore: Johns Hopkins UP, 2013), p. 163.

27 The Times, 11 Aug 1828, p. 2.

28 All of these works appeared in one publication, the Bombay Gazette: Byron, 'Isles of Greece' (20 March

1822); Campbell, 'Song of the Greeks' (28 May 1823); Campbell, 'Spanish Patriot's Song' (24 December 1823). Other papers carried these and/or similar works.

29 Máire ní Fhlathúin, British India and Victorian Literary Culture (Edinburgh: Edinburgh UP, 2015), pp. 12931. 
'freedom's tardy hand' might 'confer, | A wreath on him who died for her'.30 In evoking this wider context in India, Thompson is both responding to the surge of interest in nationalist causes across Europe, and inviting British readers to recast their own conception of the British role in India.

India does this in two ways: first, it draws parallels between the case of Britishgoverned India and examples taken from Europe of subject peoples who revolt against a tyrannical oppressor; and secondly, it does so using explicitly the language of nationhood and national identity. The British in India are unequivocally represented as exploitative, without pity for the 'millions' of Indians 'crushed by [their] control':

We live among them like a walking blight,

Our very name the watchword of affright;

No sympathy, no pity, no remorse,

Our end is profit, and our means are force;

We're always taking and we never give;

We care not if they die or if they live (79).

The poem sets the experience of India under this administration in the context of European history, describing three episodes, each cast as an instance of tyranny met with heroic resistance. Joan of Arc, religious inspiration and military leader of the armies of Charles VII of France, defeated English forces in several battles during 1429. In doing so, she 'gave a second soul to dying France', and raised 'a fierce, exulting host', which 'swept their conquerors' from the land (81). The 'eight hundred years' (82) of Muslim rule over parts of Spain ended in 1492, when the last remaining Muslim stronghold of Granada was re-taken by the combined forces of Ferdinand of Aragon and Isabella of Castile, creating a united Christian Spain. Finally, the 'moody tyrant' (83) Charles of Anjou imposed a harsh regime during his reign over thirteenth-century Sicily. These events, and particularly the 'Sicilian Vespers' rebellion that ended Charles's rule in Sicily, are common currency in the literature of the Romantic period, from Robert Southey's Joan of Arc (1796) to Felicia Hemans's The Vespers of Palermo (1823). Thompson recuperates them for an anti-colonial cause, making the sufferings of Europeans secondary to those of India: 'Yet what are these oppressions, each and all', the narrator asks, 'To the keen misery of India's thrall?' (83).

In thus developing the narrative of India as equivalently persecuted and equal in potential for rebellion to these European models, the poem also goes beyond a concern with 30 Thompson, City of the East, p. 45. 
the suffering of individuals, choosing instead to identify the subcontinent as an entity in itself, implicitly constructing the entire territory under British control as unified by its opposition to that control. It was 'ignorance and dread', the narrator claims, that 'bowed beneath our yoke a nation's head' (80); and India's anticipated revenge is described as 'the vengeful blow, | That pays a nation's mighty debt of woe' (81). With this vengeance, the demise of British rule is anticipated as well, as the masses of India are transformed into a 'nation ... aris[ing] to life and light', and the downfall of its erstwhile oppressor is celebrated without reserve: 'The murky cloud has glided from the sun, | The tale of England's tyranny is done' (85).

As well as thus deploying the rhetoric of European nationalist insurrection, Thompson's work also reverses the teleology of the narrative of colonial progress current at the time, developing instead an account of British-driven regression. In this version, Hindu India is cast as an idealized, and democratic, society:

Thus each was happy in his destined lot,

And blessed the happiness denied him not.

None then could take the peasant's hard-earned store,

And make it crime in him to have no more.

None then could keep the famished at his gate,

And when they cried for justice bid them wait;

There was no power above the people's voice,

And none could stand but on the people's choice. (6)

When this Utopia is ruined by the invasion of 'Tartar Muslemans, accursed horde!' (7), the arrival of Western power in India is presented at first as a sign of hope: the 'stranger people' will 'to the battle rise, | Roll o'er the country like the orb of day, | And drive the darkness of Islám away' (14). This soon gives way to a new oppression, as the narrator accuses Britain in India of aggression that eclipses that of its predecessors:

You injure more than those you overthrew,

And Britain! what were they, and what are you?

You a wise nation, they ferocious bands,

Your creed prohibits it, their creed commands (17)

In constructing this account of the Muslim rulers of India as second in culpability to the British, Thompson again seizes the prevailing narrative of Indian despotism, described by Metcalf as the 'central representational mode' of British colonialism, and reverses it.31 Britain 
does not save India from the violence of the Mughals and their successors, but out-despots them. While other writers of the time represent the British influence in India as a civilizing or progressive force-Emma Roberts's poem 'The Rajah's Obsequies' (1830) strikes a key note with its image of the widow doomed to burn in sati who foresees the submission of Hindu India to the 'west's pale warriors'-Thompson's work holds firmly to its representation of British rule as worthy of the 'torturing vengeance' that India anticipates (85).32 It is a view the more surprising for being voiced from within the Company establishment, by someone aligned by profession and training with the colonial enterprise.

India thus demonstrates how Thompson's work is in some respects anti-orientalist, using the discourse of nationalism to create equivalence between India and the countries of Europe, and equating British rule as equivalent to Eastern despotism. At the same time, other aspects of India also indicate that Thompson's project involves a late revival of earlier Romantic-period metropolitan attitudes towards the Orient.33 A key strand of this thought was a conflicted sense of Britain's role and culpability in the East. Indeed, India's condemnation of the British as more tyrannical than those they replaced echoes the accusations made by poets such as William Cowper, whose 'Expostulation' (1782) may have provided Thompson with his inspiration:

Hast thou, though suckl'd at fair freedom's breast,

Exported slav'ry to the conquer'd East,

Pull'd down the tyrants India serv'd with dread,

And rais'd thyself, a greater, in their stead...34

The works of Cowper and fellow abolitionists also inform the impassioned rhetoric of India, as Thompson reiterates the appeal to humanity that forms an integral strand of the abolitionist case. (This is noted by a contemporary reviewer in the Meerut Universal Magazine, writer of one of the few extended notices of India, whose flippant remark that the author was ‘born on Clapham Common' identifies Thompson with the Clapham Sect of

32 Emma Roberts, Oriental Scenes, Dramatic Sketches and Tales, with other Poems (Calcutta: Calcutta Depository, 1830), p. 37.

${ }_{33}$ See A. Roy, Civility and Empire: Literature and Culture in British India, 1822-1922 (Abingdon: Routledge, 2005), pp. 81-89.

34 William Cowper, The Poems of William Cowper, ed. by John D. Baird and Charles Ryskamp, 3 vols (Oxford: Clarendon, 1980-1995), II, 306. A volume of Cowper's poems is listed among the books in Thompson's possession at his death (Inventories and Accounts). Thomas Campbell's The Pleasures of Hope (1799), an extremely popular work, contains a similar accusation of British colonial guilt and hypocrisy (see Rudd, Sympathy, pp. 4-5). 
evangelical reformers including William Wilberforce.35) The mistreatment of colonized Indians is compared to that of the 'very slaves that western gold has bought' (India 24).36 In this Thompson echoes again the strategies of earlier abolitionist writers, such as the pseudonymous 'Timothy Touchstone', who similarly brings together the experience of Indians subject to the exploitation of 'British Nabob's' and that of slaves on the plantations of the West Indies.37 The contemporary representation of abolition as a humanitarian achievement-'one of the greatest blessings' of the time-makes the comparison with the East India Company's actions in India the more pointed.38

These eighteenth-century texts also tread an uneasy line in relation to the precise location of responsibility for the acts of persecution they describe. While the agents of colonialism - in this case, the Nabobs - are condemned, they are simultaneously distanced from British metropolitan society, partly through their lower-class status, but also through references to the corrupting and transforming effect of India itself, which Orientalizes those who live there. 'With the wealth of the East, we have too imported its vices', remarks The Nabob's Lady Oldham of the tellingly yellow-faced Matthew Mite, his complexion 'tinged by the East'.39 Tea and Sugar's call to 'Briton's' to recognize the harm done by the 'savage band' of colonizers in India implicitly distinguishes one from the other (9-10).40

Thompson, similarly, distinguishes between Britain per se, and the British in India, rather as an earlier generation had set apart the 'Nabobs' as unrepresentative of Britishness. Britain is 'First [among nations] in thy greatness, happiness and worth; | Thy peasants fearless and thy nobles kind, | Thy justice equal to the prince or hind' (India 75). In a

35 'Review of India: A Poem, by A Young Civilian of Bengal', Meerut Universal Magazine, 1 (1835), 94-103 (p. 94).

36 A series of measures against slavery during the early nineteenth century included the Act for the abolition of the slave trade in 1807, and the Act of 1833 for the abolition of slavery throughout the British colonies. The latter Act specifically excluded the East India Company's territories, though Thompson does not appear to be targeting slavery in India in these lines, rather the condition of colonized Indians more generally.

37 Timothy Touchstone, Tea and Sugar, or the Nabob and the Creole: A Poem (London: Ridgway, 1792), p. 1. Further references are included in the text.

38 Thomas Clarkson, The History of the Rise, Progress, and Accomplishment of the Abolition of the African Slave-Trade by the British Parliament, 2 vols (London: Longman, Hurst, Rees, Orme, 1808), I, 9. 39 Samuel Foote, The Dramatic Works of Samuel Foote, Esq, vol. 4 (London, [1778]), pp. 13, 31). 40 On the 'Nabob' controversies and associated literary texts, see Tillman W. Nechtman, Nabobs: Empire and Identity in Eighteenth-Century Britain (Cambridge: Cambridge UP, 2010); Renu Juneja, 'The Native and the Nabob: Representations of the Indian Experience in Eighteenth-Century English Literature,' Journal of Commonwealth Literature 28.1 (1992), 183-198; Jyotsna G. Singh, Colonial Narratives, Cultural Dialogues: 'Discoveries' of India in the Language of Colonialism (London \& New York: Routledge, 1996), pp. 52-78. On the 'Indianized' body of the Nabob, see also E. M. Collingham, Imperial Bodies: The Physical Experience of the Raj, c. 1800-1947 (Cambridge: Polity, 2001), pp. 33-36. 
technique familiar to an earlier readership, the narrator positions the British in India apart from those of the homeland, allowing it to continue to be upheld as ideal even while the actions of British colonizers are condemned. The entity the narrator calls 'my country' (24), is held to be not culpable - 'Well I know | Thy spirit is not, cannot be so low' (24) —and the behaviour of the British in India is blamed on local conditions-'the dull, obdurate spell, | That binds our feelings in this land of hell' (25) — and the 'sordid souls too narrow to be just' (25) who carry out these oppressive acts and bring guilt to Britain by association: 'Theirs is the cruelty, the profit theirs, | And yours the guilt and infamy it bears' (25). The final lines offer a way for Britain to be redeemed by reinstating its own values, as the poet addresses 'My country!' (89), and seeks its reformation: 'Be but thyself, and let the East confess | The justice which thy western children bless' (89). This will eventually bring about the desired utopia: 'O'er all the East shall spread the reign of peace' (90). He appeals to the 'strength' and 'virtue' inherent in Britain, saying that 'guilt' and 'peril' will be overcome: 'thou art changeless as the rolling sun: |'Tis but for thee to will, and it is done' (92). The result is that British actions are caused by weakness, but a weakness only in that Britain fails to counter the malign influence of India itself — as with the Nabob texts, India is in the end represented as being at least partially responsible for its own predicament. With this turn, the discourse of orientalism intersects with that of nationalism within India, the remnants of the former visible amid the latter.

\section{The turn against Orientalism in India: Thompson as Company poet}

Thompson was, like Jones, employed in the Bengal civil service, though at the lower level of magistrate and collector-in effect, the judicial and revenue representative of the Company in a succession of provincial stations across north India. His annual salary is given in the Civil List for 1842 as Rs. 12,000 or approximately $£ 1200$ a year.41 Jones was paid $£ 6,000$ a year on his first appointment to the supreme court in Calcutta in 1783.42 This discrepancy sets Thompson far apart from Jones, and aligns him with the Company poets of the early nineteenth century, a generation of writers whose lower professional status and relative poverty contributed to a different view of India and of the East India Company. While Orientalist scholarship was intellectually fascinating and professionally profitable to Jones, some among the later generation of Company employees singled out this aspect of their 
training as a particular object of resentment. The protagonist of the anonymously-published 'Rinaldo, or the Incipient Judge', for example, finds his education in the languages and literatures of the East of no use as he sets out to hear 'a case | Of which one syllable he could not trace!'43 Similarly, Sir Anthony Fudge — recent graduate of the Fort William College and newly-appointed assistant to the judge at an 'up-country station'-regards his education with such contempt 'that the Diploma, or rather Degree | With which they'd had the goodness to decorate me, | I'd affixed to a drum, and had made it a toy $\mid$ For the use and diversion of Billy, my Boy'.44 Some of these texts target Jones himself, as when the deluded parents of Tom Raw, the Griffin find their mistaken notions of Indian riches informed by the Jonesian 'sparkling gems of Samarcand'.45 (The author, Charles D'Oyly, and his probable collaborator James Atkinson, were of an elite class, not comparable to the poverty-stricken protagonists of the Company satires, but, as Leask suggests, Tom Raw reflects the 'anti-orientalist mood' of the period.46) David Kopf, who originally identified this category of anti-Orientalist texts, suggests that this resentment may be owing to those who did not 'make the grade' in terms of linguistic proficiency and understanding of India being assigned 'lesser posts in the interior' rather than higher positions.47 Thompson clearly does not fall into this category, and his writing eschews the prevailing comic and satiric mode of Company poetry, tending more towards earnest melancholy. These attributes notwithstanding, India evokes the same resentment of privilege apparent in the debt-ridden protagonists of Quiz, The Grand Master (1816) or the anonymous Life and Adventures of Shigram-Po (1821), as the narrator contrasts the rich and frivolous who thrive because of their connections, and receive 'fifteen hundred pounds a year' with the 'honest worth [who] must keep itself alive, | (And here 'tis all it can do) upon five.' 48 Despite his neo-Jonesian attitude to India, then, it seems appropriate to consider Thompson's work as a version of this Company poetry.

India: A Poem traces the path of a fictional avatar of the author - the identification is clear in the 'young civilian of Bengal' listed on the title page - as he moves from the 'College months' to the post of 'officer' in a 'province' (37), and his subsequent life in that role. While

43 Calcutta Journal, 16 Feb 1822.

${ }_{44}$ Calcutta Journal, 27 June 1820.

${ }_{45}$ Charles D’Oyly, Tom Raw, the Griffin (London: Ackermann, 1828), p. 3. Compare Jones's well-known poem

'A Persian Song of Hafiz', in Jones: Selected Works, ed, by Franklin, p. 186.

46 Leask, p. 81.

47 David Kopf, British Orientalism and the Bengal Renaissance: The Dynamics of Indian Modernization, 1773 -

1835 (Berkeley: U of California Press, 1969), p. 222.

48 Quiz, The Grand Master: or, Adventures of Qui Hi? in Hindostan (London, 1816; rpr. Posner Memorial

Collection); Life and Adventures of Shigram-Po (Calcutta, 1821), p. 63. 
the main focus of Company poetry is the trajectory of the protagonist, in India, the trope of the naïve young man's gradual recognition of injustice and mistreatment is used to highlight the plight of the Indian subjects of the Company. When the protagonist notes the poverty of the countryside, it is explained to him that the 'only pestilence is greedy power' (38); and that the driver of a phaeton whose practice is to 'curse the haggard throng' is not a 'base born knave' but his own superior (39), drunken and oppressive, who is paid 'Three thousand pounds a year' (40). 'Has he no pity', the protagonist asks, and is told 'None- he had once' (40); with the explanation that 'In India, he whose pity never sleeps, | Must be more wretched than the race he weeps' (41). To the question of who is to blame, the answer appears to be the East India Company and its policy, shaped by those 'men whose system makes him so remiss: | Those who have thrown the work of ten on one, | And never looked to see if it was done' (41). The result of this misgovernment is anticipated by the narrator in Canto III of the poem, in the shape of an imagined rebellion of Indians against Company rule and a 'wideleagued massacre' of the British (85).

While this narrative trajectory sets India apart from other versions of the Company servant's encounter with India - and the identification with the colonized certainly does go beyond anything in the other texts discussed here-Thompson as liberal sympathizer with India and Indians nonetheless shares with other Company poets a preoccupation with the lives and troubles of British men. The most noteworthy aspect of the poem, for a reader necessarily seeing it through the lens of later events, is the imagined rebellion of the colonized; but this is arguably not its main concern. The text describes at more length, and with more feeling, the unhappiness of its protagonist, the 'young Briton, fresh from freedom's isle' (34), whose positive and well-meaning qualities are insisted upon: he seeks out the 'noble' and avoids the 'base', and the 'blush of virtue mantles o'er his face' (34). He takes upon himself the 'task' of righting the wrongs he sees around him:

His fancy sees, and blushing thrills to see,

The rulers temperate, the people free,

Unmasked oppression driven from the laws,

A world called back to life, and he the cause (35)

He fails in this attempt, but his failure is blamed ultimately on the institution within which he functions, as he is constrained by the Company's policies, of which he, as well as India, is a victim:

In the night's silence, when none else can hear,

The people's cry comes rushing on his ear; 
He lives a conscious minister of ill,

Hates all the deeds he does, and does them still;

His plea- that this the Government exacts-

Theirs is the law, the guilt, and his the acts. (52)

The poem also demonstrates the limits of its author's sympathy with India and Indians, as becomes clear when it is compared to an earlier work mentioned above, The Grand Master. Like Thompson, the pseudonymous author Quiz highlights various forms of British abuse in India, from the 'pamper'd British Nabob, | That luckless natives ev'ry day rob', to the 'Burra Sahib' (the Governor-General, Lord Moira) who 'Treads on the hapless natives' necks, And horror thro Indostan strikes'. But the poem also suggests imagined forms of cross-cultural cooperation and compassion, albeit constructed on narrative cliché and stereotype, as the protagonist Qui Hi saves a 'Hindoo's daughter' from accidental death, and years later finds his debts paid by the 'grateful Indian' in return.49 While the protagonist of India similarly sees the British administration as catastrophic for India, Thompson envisages no similar emotional connection or collaboration between individual colonizers and colonized, who remain distanced from one another throughout.

The later poem 'City of the East' takes this disconnect a step further, as the colonial encounter is represented as itself victimizing both its participants, alienating each from the other: the 'golden chain', offered by Indians in 'feigned humility' to those who would be their 'Lords', turn out to be 'fetters'.50 Similarly, the relationship of colonialism is characterised by mutual entrapment:

The very palaces were spacious prisons,

Gated, and barred, and most obsequious knaves,

(To man's perceptions) bore a gaoler's key,

And ruled the movements of their subject Lords (15)

Thompson's protagonists thus find themselves ensnared by a combination of their own will to power - the dream of being 'Lords of this fair city' (18) — and the duplicity of Indians. The protagonist, in both poems, seems aware of this dysfunctional relationship but unable to counter it. Rather, the hyperawareness of personal responsibility and inability to contend against the system of Company government manifested by the protagonist of India seems to alienate him from both colonizer and colonized.

49 Quiz, Grand Master, pp. 101, 108, 103.

50 Thompson, City of the East, p. 18. Further citations are included in the text. 
This becomes particularly apparent in the depiction of India's imagined uprising, when the speaker creates distance between the British victims of rebel action and himself: 'Oh! spare them, Indians! cruel though they be, |Oh! spare them! spare them! for their land and me' (86). The scenes of rebellion and catastrophic retribution enacted upon the bodies of the colonizers are described with a sensationalism that anticipates the modes of writing, as well as the events, of 1857-58:

Then shrieks the wife above her murdered lord,

Then gasps the stripling quivering on the sword,

Then writhes the virgin in the ravenous clutch

Of him it seems pollution but to touch,

Then raves the mother o'er the mangled child,

Torn from her bosom as it played and smiled,

And oh! the torments of the captured few!

Rise, reeking earth, and hide them from my view (86-7).51

Sensational though these lines undoubtedly are, the fates of these stereotypical victims, recounted with gusto, appear to elicit nothing like the sympathetic response the poem seeks for its protagonist, as it insistently dwells on his high, though ultimately failing, aspirations: 'youth's aspiring aim | Struck down and crushed beneath the load of shame' (54).

Responsibility is diverted from him to his superiors, as he 'must learn from them | To bind or loose, acquit men or condemn' (55). Other passages emphasize his loneliness, haunted by the 'thought of home' (57). The pathos of his situation is heightened at every turn: despite his recognition at 'school and college' as the 'brightest, warmest, noblest, ablest, best' (58), he is condemned to 'waste away without a name, | While duller spirits o'er him climb to fame' (59). In the last analysis, the poem's main quota of imaginative investment appears to be reserved for its protagonist and his own awareness of inadequacy and failure. This emphasis on the thwarted protagonist has effect of shifting the reader's attention from the people of India to his own plight, and by extension to the circumstances of Thompson himself as the 'Young Civilian' of the title page.

51 Compare, for instance, the rollcall of victims in Gerard Massey's 'Havelock's March', including the 'ruddy stripling', the 'Maiden', the 'Mother great with Child', and the 'Babe, that smiled up in [its attacker's] face', in Havelock's March and other Poems (London: Trübner, 1861), p. 14; or Mary E. Leslie's sonnet sequence, with its account of the 'frantic woe of women forced to see | Their tiny infants ... | Dashed down upon the ground unpityingly', in Sorrows, Aspirations and Legends from India (London: John Snow, 1858), p. 13. 
This personal element to the work is observed by the Meerut Universal Magazine reviewer, who ascribes the views of the author to his being a 'disappointed applicant' for promotion, too 'young in the service' to be familiar with the reasons for the Company's procedures and in need of a wife to 'prevent him moping'.52 Such a reaction-quite distinct from those of metropolitan reviewers - alerts us to an abiding difference between Thompson's situation and that of both the Company poets and the anti-colonial metropolitan writers discussed above. 53 Unlike those writers who commented from outside the East India Company, and also up to a point unlike Jones, who was protected by his status and position, Thompson had to negotiate the role of a relatively low-ranking Company servant, among a wider émigré community where the main current of thought ran counter to his own. His poetry suggests that he was intellectually and emotionally at odds with his role and his colleagues, and subject to the conflicted loyalties arising from his position as employee of the Company and critic of its policies and practices. The remainder of this essay examines Thompson's work in the light of his individual circumstances, both personal and to do with his role as poet.

\section{The poet's role in colonial India}

The figure of the Company servant in India, complicit by his employment in a regime that he despises, immediately brings to mind parallels with Thompson himself. No letters or biographical writings of his have emerged, but there does exist material that sheds some light on the circumstances of his life and employment. These are letters written by his brother, George Frewin Thompson, six years his elder, who also served the Company in Bareilly from 1826 until he died of 'bilious fever', aged 29, in 1834.54 Five years after George's death, Thompson compiled a privately-printed edition of some of his poems and other writings under the title Footsteps of One Departed: Or, Specimens in Verse and Prose. The letters in this collection, written by George to family members including William, illuminate the conditions they both encountered in India. The onerous workload is a reiterated theme: in March 1833, George describes himself as 'working slavishly; twelve hours a-day, with a

52 'Review of India', M.U.M., pp. 99, 101, 102.

53 The Monthly Repository reviewer, for instance, approved the author's 'strong purpose', even while expressing doubt about the suitability of 'three cantos of heroic verse' for a 'sort of business ... now always transacted in prose' ('Review of India: A Poem', Monthly Repository, May 1834, p. 384.) See also reviews in the Athenaeum, 14 June 1834, p. 449; Metropolitan, June 1834, p. 45; Gentleman's Magazine, December 1834, p. 624; Tait's Edinburgh Magazine, July 1834, p. 432.

54 Asiatic Journal, July 1834, p. 201. 
wretched court-house; the more unsatisfactorily, as I differ toto coelo from my predecessor and my superior'. This implication that the difficulty of the writer's situation is exacerbated by hostile colleagues echoes similar observations in India, where the protagonist is dismayed that those 'Whose deeds he hates, whose intellect he scorns, | Must be his masters...'. A later extract advises his brother: 'Do not for any consideration work more than six hours a-day in your office. ...I am quite sure that about double that is beyond any constitution.... Ten hours a-day killed Leyden, and nine poor Sloane'.55 The writer was himself dead less than a year later.56 Thompson's response in 'Lines on the death of a brother' makes it clear that he shared this view of India's effect upon those who worked there and found themselves: '[c]hained slave-like to the burning soil | When all the love of life was spent' .57 The feelings of alienation and imprisonment apparent in such writings also recur in relation to other aspects of British life in India, including its physical environment. Creativity is unattainable, according to India, in a place beset by 'the sun's insufferable ray' (1); and the landscape is imagined in terms of a melodrama of oppression: 'Mute Nature droops her unresisting head | Still fainting with the glow of yester's heat, | A victim crouching at the oppressor's feet' (29).

'City of the East' further develops these extended metaphors of oppression, exploring the relationship of entrapment between colonizer and colonized discussed above, and culminating in the narrator's account of the 'unheard' shades of his vision speaking their exhortation:

Fly from the shores where guilt and folly spread,

The thousand snares of many-coloured death,

Where life is emptiness, where joy is pain,

And death itself no rest, but toil confirmed (32)

The poem also, however, demonstrates some of the potential for poetic innovation apparent in Thompson's situation, in ways that may go at first unnoticed amid the overwhelmingly

55 Footsteps of One Departed: Or, Specimens in Verse and Prose (London, 1839), pp. 79, 55, 80. John Leyden (1775-1811), a linguist and poet, died of fever apparently developed as a consequence of visiting an 'unventilated native library' (T. W. Bayne, 'Leyden, John (1775-1811)', rev. Richard Maxwell. Oxford Dictionary of National Biography. Oxford: Oxford UP, 2011. n. pag.). I have not identified 'poor Sloane'. ${ }_{56}$ Footsteps of One Departed is anonymous, and its author has not previously been identified, but the family relationships and the chronology of events and publications associated with it both correlate with the Thompsons' lives. The papers of the 'gentleman lately deceased' are stated in the introduction (dated May 1839) to have been in the editor's possession for five years (iii), which tallies with George Thompson's death in January 1834. Multiple copies of the work (which was never published) were among William Thompson's possessions sold at auction after his death, as was also the case with other works authored by him, whereas no books by others are listed other than as single copies.

57 Bengal Annual, 1836, p. 312.

Ní Fhlathúin 21 
pessimistic nature of its vision. This potential derives from his access to multiple discourses and frames of reference, and in this specific case, from his knowledge of two traditions: the developing body of colonial poetry describing the encounter with India, and the contemporary metropolitan turn towards the medieval as part of a Romantic-era preoccupation with geographical and historical others. In the colonial tradition, James Atkinson's 'City of Palaces' (1824) offered Thompson a model of a multivalent approach to the British role in India. This is evident in the third stanza of the poem, where the protagonist's first encounter with India is viewed both as it happens in the past and as it is looked back upon from the present, with an equivalently double vision of the protagonist himself, both a 'thing of nought' and — transformed by the colonial relationship — become elite in India:

When first I stood upon the landing place,

Of the proud City of the gorgeous East,

I saw a swarthy turban-covered race,

Whose noise and tumult momently increased;

They looked as if from Bedlam just released;

A Babel of strange tongues encompassed me,

Fawning for service, so I thought at least,

And I, a thing of nought, a worm, to be

Thus hailed upon the shore, like Knight of high degree.58

'City of the East' (which derives its title and its starting-point from Atkinson's work) recreates this dual perspective, but where Atkinson celebrates the buildings of Calcutta - 'the pomp of spires | And palaces, to view like magic brought: | All glittering in the sun-beam' (7) - Thompson replaces brightness and order with a landscape of confusion and chaos:

I saw a city in the golden east-

A wilderness of pomp; on every side

Pile upon pile redoubled, endless, lost,

In rich confusion glaring back the day,

Baffled the sight, and drove the spirit back

All trembling at its impotence aghast.

Temples were there and spires, the work of years

58 James Atkinson, The City of Palaces: A Fragment, and Other Poems (Calcutta: Government Gazette Press, 1824), p. 6. Further citations are included in the text. 
And eager toil achieved, that vainly strove

To top the maze of grandeur; dwindled, lost,

Unnoticed stood they pointing at the sky (1)

In this panorama of futility, the protagonist encounters an apparition far removed from British India, a 'stately form ... all glowing white' with a 'Palmer's crozier ... within his grasp' and a 'Palmer's wallet at his girdle hung' (9). He leads the narrator on to a point of order within the architectural chaos, where among 'unnumbered piles | High reared o'er all ... |A single tower rose beaconing to the sky' (9). The narrator climbs it to the 'utmost height' and sees around him 'the well-known scene, ne'er seen as now'. The sun is replaced by a 'golden eye' (11), by the light of which the city is seen anew:

Doubt and dim

Uncertainty, deject, the specious shows

And empty gew-gaws, unsubstantial masks,

Mocking the bitterness of life's despair,

Touched by that solemn look fled far away.

Like morning mists. (12)

While the ruined oriental city is in itself a reasonably common trope in metropolitan Romanticism (Southey's fallen cities of Bagdad and Babylon, for instance, may underlie the nameless 'City of the East'), the 'tower of Truth' and the vision of the Palmer both signal Thompson's use of a motif from Romantic-period medievalism.59 They recall similar constructs in medieval dream-vision poetry, most immediately the 'tour vppon the tofte' (tower on the hill) where 'Treuthe is ther-ynne' in the fourteenth-century poem Piers Plowman, and the description of Piers himself as a 'palmere' or 'palmare'.60 The indirect source for this is T. K. Whitaker's Visio Willi de Petro Plouhman (1813), the first edition of the poem published since the sixteenth century.61 While Thompson probably did not encounter this work directly-it was an expensive edition, published in a form unlikely to be read by many 62 - he is more likely to have read a review by Thomas Wright published in the

59 Robert Southey, Thalaba the Destroyer (London: Longman, Rees, 1801; Oxford: Woodstock, 1991). I am grateful to $M L R$ 's anonymous reader who alerted me to this reference.

${ }_{60}$ William Langland, Piers Plowman: A New Annotated Edition of the C-text, ed, by Derek Pearsall (Exeter: University of Exeter Press, 2008), pp. 56, 251, 256.

61 T.K. Whitaker, Visio Willi de Petro Plouhman (London, 1813). See David Matthews, The Making of Middle English, 1765-1910 (Minneapolis and London: University of Minnesota Press, 1999), p. 90.

62 Charlotte Brewer, Editing Piers Plowman: The Evolution of the Text (Cambridge: Cambridge UP, 1996), p. 45 . 
widely-circulated Gentleman's Magazine in 1834, three years before City of the East appeared. Wright was mainly concerned with Whitaker's choice of manuscripts and scholarship, but in the course of discussing the merits of various manuscripts, he included several extracts from the text of the poem, among them both the description of the tower on the hill mentioned above, and an account of the gathering of 'pilgrymes and palmeres', thus furnishing the inspiration for these elements of 'City of the East', as well as the central trope of the poet's vision.63 With this repurposing of Piers Plowman, Thompson can be seen as part of the broader nineteenth-century current of antiquarianism, and of the contemporary 'general interest in medieval literature'.64 This association is strengthened by his possession of a copy of Chaucer's Canterbury Tales, suggesting a wider interest in the medieval rather than simply a chance reading of Wright's review.

More broadly still, Thompson's work can be regarded as a late exploration of the poet's role in relation to civil society, drawing on the tradition of metropolitan Romantic poetry that sets the figure of the poet centre stage. In India, the protagonist's own selfperceived weakness - he sees himself as 'a lone and blighted man' in 'this benighted land' (26) — is countered by his sense of his role as that of a prophet: 'My voice shall strike in thunder on thine ear | And chill thy bosom with a tyrant's fear' (26). His stand against 'selfishness' (70) may be self-aggrandizing, but this does not necessarily negate its sincerity: 'It is because he loves his kind too well, | His soul in bright Utopias seeks to dwell' (70). He pursues this goal through the means of poetry, with the aim that 'Whate'er he writes must have this secret plan, | The love of virtue, and the good of man' (73). This clearly reflects Thompson's own sense of himself as set apart from and following a different agenda to his colleagues and compatriots in the service of the Company - the same quality unkindly skewered by the Meerut Universal Magazine reviewer, who surmised that 'he reckoned himself much cleverer than his Superior, and perhaps he was; but still he should have kept it to himself' .65 But it also reflects the Romantic-period concern with the role of the writer as speaking to and for others, the sense of what literature is and does that produced Cowper's abolitionist poems evoking the 'nat'ral bond | Of brotherhood' broken by slavery in 'The Task'; or the Lyrical Ballads' vision of the poet as a 'man speaking to men'; or perhaps even Shelley's idea of poets as the 'unacknowledged legislators of the world', a phrase written in

63 Thomas Wright, 'The Visions of Piers Plowman,' Gentleman's Magazine (April 1834), 385-391 (pp. 388 , 390).

64 Brewer, Editing Piers Plowman, p. 50.

65 'Review of India', M.U.M., p. 101. 
1821, though not published until 1840.66 When the protagonist of India proclaims his intention to '[r]aise in the wilderness a prophet's cry' (74) of warning to his fellow countrymen, it demonstrates that the familiar concerns of metropolitan Romantic-period writers are capable of being transformed as they intersect with the dynamics of the colonial encounter.

In 1830s Calcutta, cross-cultural networking resulted in the production of works by both British and Indian poets (Emma Roberts, H.L.V. Derozio, Henry Meredith Parker, Kasiprasad Ghosh) where form and content are recognizably inflected by the intermingling of Eastern and Western influences.67 Located, as he was throughout his career, in regional centres of administration, Thompson may not have had the opportunity to participate in such interactions. Though his translations show the extent of his engagement with Islamic cultures, neither this, nor his lived experience of life in India, appears to have had any substantive effect on the form, as opposed to the subject matter, of his work. Nor does this experience appear to have engendered in him any inclination to see any Indian people as individuals, as opposed to the abstracted voices of nationalist feeling of 'The Rajpoot's Lament' or 'The Jogi's Address to the Ganges'. This last point is underlined by a comparison of Thompson's characters with those of his contemporary Parker's 'Young India: A Bengal Eclogue': the latter, with their exuberant discussion of philosophy and history around the question of beefeating, are comic creations, but also recognisably engaged with the contemporary dilemmas of a changing society.68 When we consider these aspects of his work, Thompson appears to be a marginal figure not only in relation to metropolitan writing, but also in relation to the developing tradition of poetry within British India. The two most striking attributes of his life

${ }_{66}$ Cowper, Poems, II.139; William Wordsworth, and Samuel Taylor Coleridge, Lyrical Ballads 2 vols. (London, 1802), I.xxviii; Percy Bysshe Shelley, Essays, Letters from Abroad, Translations and Fragments, ed. by Mary Shelley (London: Edward Moxon, 1840), I.57. These examples of Romantic-period formulations of the writer's role clearly raise issues of sex and gender, which lie beyond the scope of this essay; however, Thompson's work focuses almost exclusively on male protagonists, with the main exceptions being the stereotypical 'wife' 'virgin' and 'mother' imagined as falling victim to Indian rebellion. It seems appropriate, therefore, to place him in the tradition of masculine Romanticism.

${ }_{67}$ Examples include the versions of the sati narrative produced by Derozio and, following him, Roberts (see Mary Ellis Gibson, Indian Angles: English Verse in Colonial India from Jones to Tagore (Athens, OH: Ohio UP, 2011), pp. 92-97); H. M. Parker's satirical 'Oriental Tale' (Bengal Annual, 1833, 1-16) based on linguistic and cultural code-switching (see Daniel White, From Little London to Little Bengal: Religion, Print and Modernity in Early British India, 1793-1835 (Baltimore: Johns Hopkins UP, 2013), pp. 141-43). Rosinka Chaudhuri, Gentlemen Poets in Colonial Bengal: Emergent Nationalism and the Orientalist Project (Calcutta: Seagull, 2002), discusses further works in this category by Kasiprasad Ghosh, Michael Madhusudhan Dutt, Derozio and others.

68 H.M. Parker, Bole Ponjis. 2 vols (London: Thacker, 1851) II.223-8.

Ní Fhlathúin 25 
and work are his own suicide, and the imagined Indian rebellion that appears to anticipate the outbreak of insurrection in 1857. The latter casts a retrospective glow of interest over his poetry, but is otherwise immaterial to its analysis. Similarly, it is tempting to read backwards from his suicide to construct his poetry as evidence of the unmanageable stresses created by the clashing imperatives of the colonial state and liberal individualism; but this also is difficult to sustain with any certainty: 'City of the East' was written at least five years before his death, and the main productions of these last five years are the translated works discussed above.

Why, then, should Thompson's work be studied, apart from its relevance as part of what has become in recent decades the Romantic-period canon's hinterland of the marginal and the neglected? First, because he is a contrapuntal voice, an anomaly, both in his attitude to Orientalist scholarship which echoes that of Jones in an era when Jones's approach no longer had currency within the ranks of the Company, and in his translation of concepts across the East / West divide to represent India in the language of nationalism. Second because, paradoxically, he is also an undistinguished writer with an unremarkable career whose work nonetheless demonstrates the depth and complexity of this tradition of poetry in British India, including as it does the colonial writer's interactions with India and the quotidian detail of days, the transnational intersection of British India and emerging European nationalism, the look to the past and the medieval heritage of English literature, and the concern shared with mainstream Romanticism over the role of the poet in relation to his community. These significant aspects of Thompson's oeuvre also highlight the uneven character of British colonialism, and the ways in which local and personal experience and intellectual engagement could produce even within the colonial administration an imaginative enterprise of cultural translation and affective identification with the colonized.

Maire.ni_Fhlathuin@nottingham.ac.uk 